\title{
Environmental impacts of a reduced flow stretch on hydropower plants
}

\author{
F. V. A. Souza-Cruz-Buenaga ${ }^{a *}$, S. A. Espig ${ }^{a}$, T. L. C. Castro $^{b}$ and M. A. Santos ${ }^{a}$
}

${ }^{a}$ Programa de Planejamento Energético - PPE, Instituto Alberto Luiz Coimbra de Pós-graduação e Pesquisa de Engenharia - COPPE, Universidade Federal do Rio de Janeiro - UFRJ, Avenida Horácio de Macedo, 2030, Centro de Tecnologia, Bloco C, $2^{\circ}$ andar, sala 211, Cidade Universitária, CEP 21941-914, Rio de Janeiro, RJ, Brasil

${ }^{\text {b}}$ Departamento de Recursos Hídricos e Meio Ambiente - DRHIMA, Escola Politécnica, Universidade Federal do Rio de Janeiro - UFRJ, Avenida Athos da Silveira Ramos, 149, Centro de Tecnologia, Bloco D, $2^{\circ}$ andar, sala 202, Cidade Universitária, CEP 21941-909, Rio de Janeiro, RJ, Brasil

*e-mail: fesouzacruz@ppe.ufrj.br

Received: August 10, 2017 - Accepted: December 8, 2017 - Distributed: August 31, 2019

(With 5 figures)

\begin{abstract}
In Brazil, given its privileged hydrology, the unexplored economic use of water resources has many dimensions, such as hydroelectric power. This energy will face increasingly rigorous social and environmental impact assessments ( $40 \%$ of potential is located in the Amazon region). Hydropower inventory studies conducted over decades, with solutions such as ecological river flows, that flood smaller areas and reduce natural river flows modifications, are being reviewed. The river extension from dam to the point where the waters are returned after the powerhouse is known as the Reduced Flow Stretch (RFS). Even mega-projects, such as the 11.3 GW Belo Monte dam, are designed with deviating flows reaching an astounding $13,000 \mathrm{~m}^{3} / \mathrm{s}$ (excavated material higher than Panama Canal). RFS requires to be carefully studied to achieve appropriate ecological flows, since RFS flows increased reduces the plant's electricity production to the same installed capacity. Balancing RFS requirements and hydroelectric power remains a challenge and, clearly, there is no consensus. Here, we performed an analysis of the main environmental impacts caused by RFS requirements, considering the multiple water use specific for each dam site. The natural variability of river flows provides diversity of habitats and maintains the richness and complexity of biological communities. Therefore, the present study has great ecological, social and economic relevance, since proper evaluation of the RFS requirements avoids potential destabilization of biological communities and even loss of biodiversity. This type of arrangement was more common in dams located in headwaters of rivers, as in the slopes of the Andes mountain range, and in regions like the Alps. There are many hydroelectric plants in South America and Europe that have this type of arrangement of engineering works. But the times are different and the environmental impacts have to be better evaluated. A final aspect also involves the maintenance of ecological flows downstream of dams. Regularization reservoirs need to keep downstream, even if they do not have a TVR, adequate flows that represent minimally the seasonality of the river, with floods and droughts, that propitiate the maintenance of the ecosystems downstream. There are cases such as the Sobradinho Plant in the São Francisco River that has been much questioned in this regard, especially when the climate is changing in the basin, with long periods of drought, and with increasing water use. So this is a very important and increasingly current issue.
\end{abstract}

Keywords: water resources, hydrology, environment, biological changes.

\section{Impactos ambientais do trecho de vazão reduzida em usinas hidrelétricas}

\section{Resumo}

No Brasil, dada a sua hidrologia privilegiada, o uso econômico dos recursos hídricos tem muitas dimensões, como a energia hidrelétrica, agricultura, abastecimento humano. A energia hidrelétrica tem enfrentado e enfrentará cada vez mais avaliações de impacto social e ambiental rigorosas (notadamente na região amazônica onde está localizado $40 \%$ do potencial). Os últimos estudos de inventário de para implantação de hidrelétricas por esse motivo tem sido feitos procurando soluções que minimizem a área de inundação e abandonando aquelas alternativas que propunham a modificação dos fluxos naturais dos rios, com a construção de reservatórios de regularização. Algumas dessas soluções de engenharia envolvem a proposição de um trecho de vazão reduzida, um trecho de rio que vai da barragem até o ponto em que as águas são devolvidas ao seu curso natural, após passar pelas turbinas, de forma a aproveitar a queda proporcionada pelo rio e pela barragem. Esse estirão fluvial é conhecido como trecho de fluxo ou vazão reduzida (TVR). Mesmo mega-projetos, como a represa de Belo Monte (11,3 GW), são projetados desta forma, com fluxos desviados por vales e canais laterais, escavados (nesse caso chegando a um surpreendente $13000 \mathrm{~m}^{3}$ (de material escavado 
superior ao do Canal do Panamá). Assim o TVR sofre um impacto severo e definitivo, local onde a vazão natural será diminuída e que precisa ser cuidadosamente estudado para se possa propor fluxos ecológicos adequados, uma vez que um aumento nos fluxos no TVR reduz a produção de eletricidade da planta para a mesma capacidade instalada. A forma de equilibrar os requisitos do TVR e a energia hidroelétrica continua a ser um desafio, e claramente não há consenso. Neste estudo, realizamos uma análise dos principais impactos ambientais causados pelos requisitos do TVR, considerando as múltiplas utilizações de água específicas para cada local da barragem. O estudo é relevante porque a variabilidade natural dos fluxos dos rios fornece diversidade de habitats e mantém a riqueza e a complexidade das comunidades biológicas. Se os requisitos do TVR não forem adequadamente avaliados, pode haver uma desestabilização de comunidades biológicas e até mesmo uma perda de biodiversidade. Esse tipo de arranjo era mais comum em barragens localizadas em cabeceiras de rios, como nas encostas da cordilheira dos Andes, e em regiões como os Alpes. Existem muitas hidrelétricas na América do Sul e na Europa que possuem esse tipo de arranjo de obras de engenharia. Mas os tempos são outros e os impactos ambientais tem que ser melhor avaliados. Um último aspecto também envolve a manutenção de fluxos ecológicos a jusante de barragens. Reservatórios de regularização precisam manter a jusante, mesmo que não tenham um TVR, fluxos adequados que representem minimamente a sazonalidade do rio, com cheias e estiagens, que propiciem a manutenção dos ecossistemas a jusante. Existem casos como o da Usina de Sobradinho no rio São Francisco que tem sido muito questionado nesse aspecto, notadamente quando o clima está mudando na bacia, com longos períodos de estiagem, e com crescimento dos conflitos de uso da água. Portanto esse é um tema importantíssimo e cada vez mais atual.

Palavras-chave: recursos hídricos, hidrologia, meio ambiente, alterações biológicas.

\section{Introduction}

Brazil has high water availability due to its privileged hydrology. It is no coincidence that $62 \%$ of the country's electricity is based on hydropower (EPE, 2016). According to Schork and Zaniboni-Filho (2017) the construction of dams for hydroelectric energy generation is now among the main anthropogenic impacts on Brazilian watersheds, substantially modifying most of the country's large rivers. Since 2004, public auctions have been organized by the government for the construction, operation and maintenance of power plants (Faria, 2011).

Historically, the hydroelectric potential of the southeast, south and northeast regions of Brazil, which host greater proportions of the population and economic development, was developed. The most significant expansions started in the 1950s based on a strategic decision made by the Brazilian government (Brasil, 2007). The expansions were particularly significant in the 1980s because of the shocks in oil prices that occurred during the 1970 s, when large electricity-intensive industries began to settle in the country. The generating capacity was mainly developed by state-owned companies until the 1990s, when institutional reforms in the electricity sector were made to attract private investors. However, due to uncertainty associated with the new regulatory framework, investments in the years that followed were modest.

Though hydropower has not yet been exhausted in these regions, the exploitation of the potential has moved to the Amazon Basin, in the northern part of Brazil. The beginning of the exploitation of the hydroelectric potential of the north region started in 1980s. In these two decades, expansions occurred mainly through the construction of large hydropower plants.

Two types of water vulnerability can be highlighted. Natural water vulnerability is present in arid and semi-arid regions under natural environmental conditions. Anthropic water vulnerability is promoted by human action in the management of water resources regarding water supply, irrigation and hydropower generation with and without reduced flow stretch.

Environmental agencies, IBAMA, ANA or departments of water resources of the states usually have the duty and power to approve the minimum downstream flow of a dam and other water uses.

The objective of this study was to conduct an analysis of the main environmental impacts caused by reduced water flow on a reduced flow stretch (RFS) or even downstream of a regularization reservoir, by the operation of hydroelectric projects in a river basin.

RFS is a term used by the energy industry to characterize the natural river stretch that has its flow reduced by the layout of a hydropower plant. It is the stretch of river that will have its flow reduced due to the exploitation of hydropower planned with water diversion schemes (by a channel or tunnel) to optimize the local hydroelectric potential (Figure 1). Therefore, RFS is the distance measured

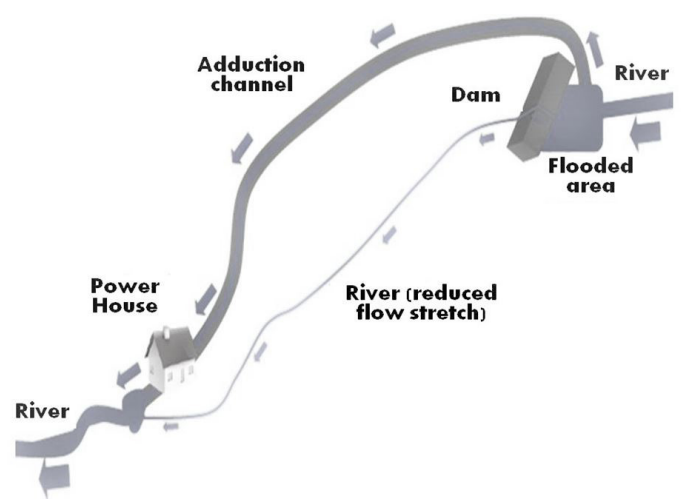

Figure 1. Schematic plan of a hydropower plant with a Reduced Flow Stretch. 
along the river course between the axis of the buffer and the return channel from turbocharged waters (tailrace) of a hydroelectric exploitation facility whose adduction is proposed by derivation.

Considering environmental and ecological issues, it is necessary to establish a remaining flow (or residual flow) in such a stretch to ensure the maintenance of aquatic life (Farias, 2014).

The reduced flow passage may be an alternative for the construction of a hydropower plant aiming to best use the falls of a site with hydropower potential, and reducing the flooded area.

However, it is noteworthy that the reduction in the impact of the RFS generates new impacts associated with this situation.

Some terminology has been used to define the flow of the RFS, such as the following according to Tucci (2012):

- Remaining Flow: the minimum downstream flow of a buffer, including the various uses of water in a river basin, including environmental uses, after such uses are granted;

- Environmental Flow: hydrograph flows that must be maintained to sustain the aquatic ecosystem under current and future conditions; and

- Sanitary Flow: a term used for the reference flow defined in the CONAMA resolution no. 357/2005 to ensure water quality when the main source of contamination is domestic and industrial sewage (Brasil, 2005).

Many power plants in Brazil were built without a remaining flow, i.e., there was no regulation of the subject. However, upon the approval of the Federal grant law (Law $\left.n^{\circ} .9,433 / 1997\right)$ and state laws (State Law $\mathrm{n}^{\circ} .3,239 / 1999$, in the case of the state of Rio de Janeiro), a minimum flow for RFS was required to ensure the environmental survival of the river stretch.

A major problem for the economic viability of hydropower plant projects with an RFS has been the definition of ecological flow. It is noteworthy that concern for the maintenance of ecological flow in stretches of rivers altered by deviations for electricity generation or regularization of flows is relatively recent in Brazil since older projects did not normally predict flows for RFS (Brito, 2009).

At the technical and economic viability stages of hydropower projects, the definition of the ecological flow value is very important because depending on the value adopted, it may cause major environmental impacts if they are underestimated, or the costs can increase such that the project is no longer viable.

According to Benetti et al. (2003), by maintaining the flow called "ecological", despite being less than natural flows, they ensure the persistence of functional and structural processes of the aquatic ecosystem, one of the variables required to enable the continuity of ecosystem functions of aquatic environments impacted by the use of water resources. Thus, it can be stated that the determination of an ecological flow is a strategy to minimize the impact of various water uses in aquatic resources.

In addition, some large hydropower projects, even without an engineering project with water diversion, have been demanded by environmental agencies to set an ecological hydrograph as close as possible to the natural flow, even for hydropower plants without reservoirs or without any regulation capacity, as was the recent case of the Baixo Iguaçu HPP. For regularization power plants, if they are implemented, the demand for this hydrograph will be even greater.

It should be noted that there are several methods for determining an ecological flow. However, they do not incorporate the extensive data of aquatic ecosystems in a robust manner and are based mainly on the analysis of hydrological indicators.

In order to achieve sustainable development in a specific region, it is necessary to know its potentialities and vulnerabilities well (Campos et al., 1997). However, according to Müller (1995, p. 270), the impacts and consequences must also be sustainable: "Although hydroelectric generation is sustainable, some regions hit to generate it had, instead of development, unsustainable retrogression".

Thus, according to the CONAMA resolution $n^{\circ} .001 / 1986$, environmental impact is

[...] any change in a physical, chemical and biological environment caused by any form of matter or energy resulting from human activities that directly or indirectly affect: I - health, safety and well-being of the population; II - social and economic activities; III - biota; IV - aesthetic and sanitary conditions of the environment; and V - quality of environmental resources (Brasil, 1986).

Following the same thought, Bolea (1989) defines environmental impact as the difference between the environment in a modified future after the completion of a project and the state of the environment in a future with a normal evolution and without a project.

Moreira (1999) conceptualized any changes in the environment as having one or more of its components caused by human action. The NBRISO 14001:2004 standard highlights the possibility of beneficial effects and defines environmental impact as any change to the environment, whether adverse or beneficial, resulting, in whole or in part, from the environmental aspects of the organization (ABNT, 2004). Sanchez (2008) adopts the concept of changes in environmental quality resulting from the modification of natural or social processes caused by human action.

The term "biotic integrity" of a water system refers to the ability to keep a community with species richness and compositional and functional organization comparable to systems not disturbed by human activities.

Anthropogenic activities exerted a profound and often negative influence on the environmental quality of continental systems, from the smallest streams to larger 
rivers. Some negative effects are due to the introduction of pollutants, while others are associated with changes in the hydrology of the basin, changes in habitats, and changes in energy sources on which the aquatic biota depends (Araújo, 1998).

In practice, there is no consensus as to which optimal flow rate is necessary for the maintenance of a water body with good water quality and volume as well as the maintenance of the environmental system since changes in environmental conditions comprise impacts inherent to the design of any hydropower plant project with an RFS. However, securing the same natural conditions of the river would be impossible without the development of alternative technology. Thus, one should focus on establishing a flow that meets sanitary, ecological and water use criteria, considering each particular case.

In addition, a new search field has been started recently. The biological aspects of these altered aquatic environments are investigated in conjunction with the hydrological and hydraulic conditions (depths, velocities, flows) imposed by the proposed engineering works. The surveys of the physical characteristics of the fluvial stretch and its historical flows associated with the biological surveys carried out before the interventions allow simulations of the functioning of this environment before and after the interventions, making it possible to define a flow or alternatives of works in the river channel that provide a view of the scenario as close as possible to the implementation of the dam of the current frame of this stretch of river, reducing the environmental impacts.

\section{Material and Methods}

A systematic review of bibliographic data on the subject was conducted in Brazilian legislation and environmental studies conducted for the implementation of projects. This study consists of a search for studies published between 1978 and 2016. A consultation was performed of books, periodicals, papers, Environmental Impact Statements and their respective Environmental Impact Reports (EIS/EIR) on hydropower plants, Basic Environmental Programs of hydroelectric projects selected through a search in a free database, and environmental agencies.

The uses of hydropower that have analysed RFS are shown in Table 1. For the quantitative analysis of the impacts, data from the Environmental Impact Study and

Table 1. Hydropower uses with Reduced Flow Stretch.

\begin{tabular}{ccc}
\hline Hydropower use & Power $(\mathbf{k W})$ & Operation \\
\hline HPP Capim Branco I & 240,000 & $02 / 21 / 2006$ \\
HPP Capim Branco II & 210,000 & $03 / 09 / 2007$ \\
SH Tombo & 2,880 & - \\
SH Bicas & 1,560 & - \\
HPP São Domingos & 48,000 & $06 / 14 / 2013$ \\
HPP Ituerê & 4,4040 & - \\
\hline HPP $=$ Hydropower Plant; SH $=$ Small Hydroelectric.
\end{tabular}

the monitoring reports of the Environmental Programs of the Belo Monte Hydroelectric Power Plant were used.

\section{Results and Discussion}

The construction of dams for electricity generation changes chemical and biological processes along streams. According to Ferrareze et al. (2015) the interruption of rivers by dams is responsible for several alterations in limnological features in the river and in adjacent habitats and in food resource availability for fish. Thus, changing the flow regime results in changes in these processes, changing the dilution capacity and impacting water quality (Nogueira, 1991).

The major impact on a plant with RFS is the creation of a "short circuit" in the river to use the natural topographic slope, disconnecting the river lengthwise and changing the water regime in reduced flow stretches (Souza, 2009). Thus, the increasing need to reconcile economic development with environmental conservation brings up the concept of ecological or environmental flow, which refers to the quantity, quality and flow regimes necessary to support aquatic ecosystems and biodiversity and to maintain ecological services on which human societies depend (Poff et al., 2010).

Hydrologic control for power generation involves the retention of the natural flow of the river so that remaining flow levels are generally insufficient for the proper functioning of ecosystems, particularly the flooding of alluvial forests, which are a key habitat for the reproduction, development and nutrition of many aquatic species. As a result, there is a decrease in the survival of critical species and organic production (WCD, 2000).

However, the larger the RFS, the greater the associated impacts. If there is a significant contribution of organic load in reduced flow stretches, the flow maintained by the dam effluence may not be sufficient to promote the dilution and maintain quality levels within an acceptable level according to the current legislation. This is characterized as an impact on water quality.

Several hydropower plants of all sizes have RFS, such as Belo Monte HPP (10333 MW), Simplício HPP (306 MW), Capim Branco HPP (450 MW), and many $\mathrm{SHP}^{1}$. Although this type of arrangement is becoming more frequent in hydroelectric projects, there are a lack of environmental impact statements from projects regarding changes and impacts caused by the reduced flow. Among the reasons for the low assertiveness of environmental predictions related to a reduction in flow, there is a lack of systematic information and research developed before, during and after the establishment of the reduced flow. There is a lack of benchmarks that allow a determination of the changes in the environmental components caused by the reduction in flow, benchmarks that enable distinguishing and estimating the actual degree of modification imposed on components, and benchmarks that allow an assessment of whether the changed component may or may not be mitigated (Bizerril and Fonseca, 2002).

\footnotetext{
${ }^{1} \mathrm{SH}$, Buritis SH, Esmeril SH, Capão Preto SH, Foz do Chopim $\mathrm{SH}$, Paraitinga $\mathrm{SH}$.
} 
According to Mortari (1997) and Engevix (2002), a decrease in discharges in a river stretch may cause different impacts on water uses and water quality. The interruption in the natural flow of the rivers damages their hydrological connectivity (Vannote et al., 1980), causing a series of changes so intense that a new ecosystem is formed (Baxter, 1977). Among these are deterioration of the landscape, exposing the riverbed and drying currents; fish mortality by stagnation of water in pools; low oxygen and isolation of stretches; the possibility of development of anaerobic conditions by decreasing the self-purifying capacity of water; a reduction in aeration capacity due to low viscosity and turbulence; and the interruption of economic activities with the consumptive use of water, such as irrigation of crops and input for public and industrial supplies.

It should be noted that the higher the RFS and the power of the plant, the higher the impact. However, even small power plants may cause significant adverse effects. Still, in hydropower plants without a reduced flow stretch, as already mentioned in introduction, the impacts have been mentioned, and mitigating actions have been required by environmental agencies.

In this case, the greatest potential for impacts is associated with how the power plant operates. In power plants without reservoirs, with or without RFS, the impacts are associated with a daily fluctuation of flows to meet a peak demand. In certain power plants, this variation may represent an oscillation $150 \%$ higher than the dry flow, when the power plant operates with one or two machines. To meet peak demands, the water discharge is even tripled.

However, the greatest impact on flows is caused by hydropower plants containing a reservoir, when even seasonality, that is, flood and drought systems, can be changed, as occurs in hydropower plants in Sobradinho and Três Marias on the São Francisco river.

It is noteworthy that in all cases, the impacts can and should be minimized by determining an energetically viable environmental ecological flow.

\subsection{Landscape deterioration}

Changes in the natural river flow by the decreasing water flow available in that stretch will result in impacts on the local landscape. Such impacts affect the natural heritage of the region to a great extent, exposing rocky outcrops (Figure 2) and eliminating waterfalls, cascades and rapids since their waters are reduced (Limiar Engenharia Ambiental, 2002).

In addition, the decrease in moisture in the RFS may also change the epiphyte community (rich in orchids, bromeliads and ferns) present in riparian forests (Limiar Engenharia Ambiental, 2002). It is worth pointing out that due to landscape changes, the populations along the RFS may experience a decrease in the available and the quality of habitats and possibly a change in prey composition.

\subsection{Plant diversity loss}

Along the reduced flow stretch, a loss of flora diversity is associated with changes in phenology and the plant composition patterns of the alluvial forest. The occurrence of this impact is certain since the flow reduction in RFS

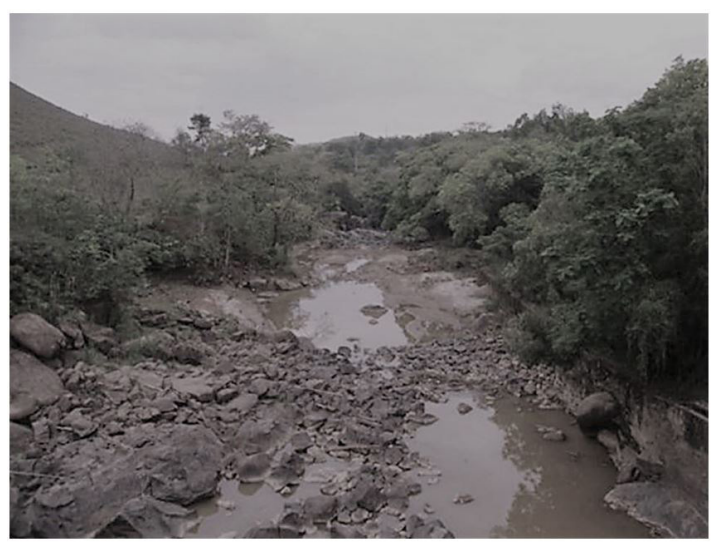

Figure 2. Reduced flow stretch of the Ituerê SH in the river Pomba, demonstrating the exposure of rocky outcrops. Source: Tarcísio Castro (Personal Archive).

almost eliminates the river overflow effect towards banks and alluvial islands, leaving this vegetation exposed to a new natural condition. However, it is possible to regard the nature of the impact as negative because there is essential habitat for fish populations associated with this type of vegetation that is directly impacted. There are also changes in nutrient inputs and a loss of primary productivity.

With respect to the alteration of the composition of the flora of the Reduced Flow Stretch of the Belo Monte HPP, through the analysis of the consolidated semi-annual reports, what has been observed is that the plants, when submerged, are in full vegetative development, adapted to constant variations such as flood pulses (influencing the seed bank formed, recruiting new individuals, developing and reproducing in the ebb, a key factor in the maintenance of the species). With the course of the measurements it is clear that the behavior of these species is closely linked to the flow and quota levels of the Xingu river.

After the completion of the reservoir filling and the start of operation of the Belo Monte HPP, it was possible to perform a general analysis of the phenological monitoring from 2011 to 2016, aiming to establish a phenological pattern for the group of podostemaceas in the pre-filling period, the impact on this group of plants, after the formation of Reservoir and RFS. Phenology of all Podostemaceae species in the phenological monitoring plots was modulated by the seasonal rhythms of the flow, according to the standards already described by Willis (1902), Philbrick and Novelo, $(1995,1998)$. However, the results to date have shown that the phenology of the species, besides depending on the flow fluctuation, depends on the vertical distribution of Podostemaceae populations in the pedals, mainly of the great waterfalls.

For the post-filling stage of the reservoir, the phenological data collected showed that the submerged plots in the Xingu reservoir had the phenological characteristics affected, with the whole phenological process and their interactions being interrupted. 
For the year 2016 (considered as post-filling), the average flow values obtained the lowest values since the beginning of the study, as well as for the entire historical series of the hydrographs of the average flows of the Xingu study. On average, the flow values considering the same period in previous years were higher in detriment to the campaign of that period. In addition, the measured values measured by the limnimetric ruler have already demonstrated the damping effect, as a consequence the flood pulse was completely interrupted at these sites (Resevoir and RFS). Thus, communities and / or populations of podostemaceae and their associated fauna that are highly sensitive to changes in flow and height (Flausino-Júnior, 2008) are no longer observed in these regions.

\subsection{Changes in the fauna community}

By reducing the river flow and the consequent loss of flooding of riparian forests and changes in flood standards in rocky environments, there is loss of natural habitat, which in turn causes changes in faunal communities. Thus, herpetofauna, aquatic and semiaquatic mammal populations are directly affected along the reduced flow stretches of hydroelectric projects.

However, the loss of flooding of adjacent forests and rocky environments causes changes in natural habitats, and there may be a reduction of food habitats. Flow reduction will result in the colonization of the river margin with pioneer vegetation, with the potential to shade possible animal spawning areas.

According to the Aquatic and Semiaquatic Avifauna Monitoring Project presented in the $11^{\text {th }}$ consolidated report of the Belo Monte Hydroelectric Power Plant, a decrease in the diversity of aquatic birds was observed after the reservoirs were filled. And although there was a decrease in diversity in all the areas analyzed, the decrease was statistically significant only in the Xingu Reservoir and in the Reduced Flow Excerpt. Also, for the bioindicator species, it was also verified that there was decrease of the diversity in the area a Downstream of the waterfall section of Volta Grande (Reduced Flow Stretch), however, these findings are preliminary considering that only two campaigns were carried out in the post-filling phase.

In the Monitoring Project of Aquatic and Semi-aquatic Mammals it was observed that there was variation in the density of sightings of giant otters along the monitoring areas between the pre- and post-fill phases. Some sections of the RFS area underwent changes in the distribution of records during the post-filling period, which became more concentrated near the downstream area of the bus.

\subsection{Reduction or elimination of populations of species intolerant to hydrological changes}

The release of a minimum hydrogram for the RFS may cause a decrease in populations or eliminate species intolerant to hydrological changes that preclude access to key resources.

These effects may be manifested in three ways:
- Loss of habitat quality in rocky environments and other habitats along the stretch;

- Loss of floodplains due to a decrease in flows;

- Loss of synchrony for vital activities, especially migratory species.

Local habitat loss may contribute to the increase in stressed fish populations with the loss of potential spawning areas, shelter from predators and juvenile and adult feeding habitats. Habitat loss always results in a decrease in the habitat capacity available so that in the vicinity of the stretch, there may be an increase in competition for better quality habitat.

The hydrologic control of the flow stretch may also impose environmental pressure on sedentary species that depend on rocky environments for survival. Although these species are not directly associated with floodplains and do not need to perform lateral or longitudinal migrations to spawn, their life strategies are closely dependent on hydrological regimes. The loss of floodplains due to hydrological control results in substantial losses of guilds of species associated with those habitats (Welcomme et al., 2006). These impacts are particularly relevant for migratory species. While some of the stocks are able to spawn, the lack of sufficient flooding to feed adult fish may cause major disruptions in food webs.

\subsection{Loss of eggs and fry downstream from hydropower plants}

Another negative aspect of the operation of hydropower plants that is normally not identified by environmental impact statements refers to the operation of hydropower plants, even those operating without reservoirs, such as small hydro plants, which are built to provide energy for the peak demand hours of the Brazilian electric system, currently between 3 p.m. and 7 p.m. Hydropower plants are operated in some released flow cases by a machine that sets flow rates for the whole set of powerhouse turbines.

If fry and eggs are downstream, they float to higher altitudes with the sudden rise of the water level. When machines are suddenly turned off at night, such individuals are trapped in the marginal vegetation. The next day, they are burned by sunlight. According to fishermen, many eggs and fry are lost in this process.

If operations were friendlier, following a gentler slope variation by turning additional machines on and later turning them off, this impact could be minimized or even eliminated.

\subsection{Fish mortality}

The reduction in flows may influence the reduction in fish species. In view of the reduction of water flow between the dam and the powerhouse, the RFS makes the biological continuity of smaller species viable only with fewer populations than previously recorded.

Furthermore, an additional impact may occur when there is a sharp decrease or an interruption of the poured water volume. This may cause fish attracted to the area to 
become trapped or be killed. The retention of fish in ponds along the riverbed becomes common. Shallow, flat and rocky bottom areas also retain fish due to the fast water flow (Limiar Engenharia Ambiental, 2002).

In recent years, experimental approaches have associated the disruption of such fish communities with the artificial reduction of flows. Among the reported negative effects, there are significant changes in taxonomic composition, a reduction of richness and density, an increase in competition and physical food space and favouring of predation, in addition to changes in the behaviour of derivative organisms (Dewson et al., 2007).

Thus, along stretches of rivers subjected to reduced flows, it is common to record a decrease in density and diversity or even the disappearance of more sensitive taxa (Cazaubon and Giudicelli, 1999; McIntosh et al., 2002; Kinzie et al., 2006). Disturbances of such a nature may therefore affect the ecological processes in which macroinvertebrate communities participate (Covich et al., 2004). The ability of such organisms to convert basal resources (plant material and debris) into animal tissue is important in aquatic food webs, whose disruption may cause changes in the supply of power to the entire ecosystem (Wallace and Webster, 1996; Graça, 2001).

It may also be noted that studies on the dynamics of fish populations correlated significantly with increases in natural mortality in tropical rivers with a decrease in remaining flows during the dry season (Welcomme, 1992) (Figure 3).

One of the strategies used in European countries to mitigate the negative effects of flow reduction on aquatic communities, especially on fish and macroinvertebrates, is the construction of small dams in regulated stretches (Cortes et al., 2002).

Using as an example the Belo Monte Hydroelectric Power Plant, one can verify through the $11^{\text {th }}$ Consolidated report the implementation of the rescue and rescue program of the ichthyofauna, which presents with one of the objectives, if necessary, the rescue of fish with

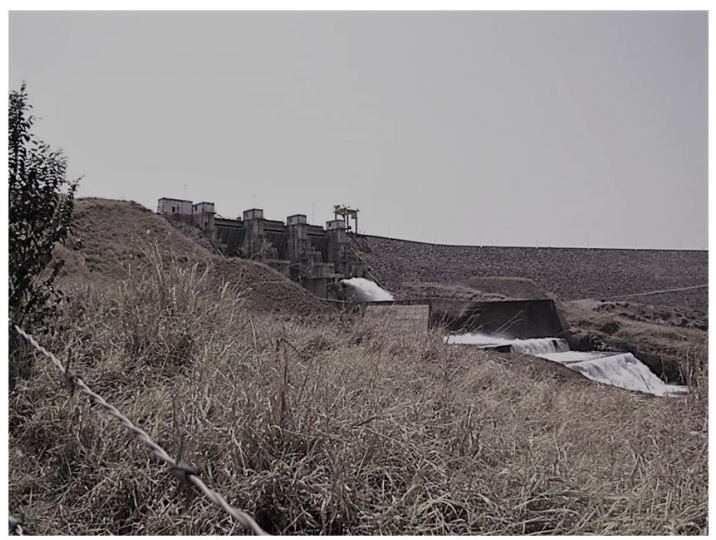

Figure 3. Capim Branco HPP: closed pourer and flow operation using valve opening. Source: Tarcísio Castro (Personal Archive). life and healthy, imprisoned between the rocks and small puddles on RFS

According to the abovementioned report, during the period from July 2016 to December 2016, 1,349.98 kg of live fish and $32.49 \mathrm{~kg}$ of fish perished in RFS were rescued. Also, through the available raw data of this monitoring program, it was possible to measure the quantity of ichthyofauna individuals that were rescued, thus determining the specimens that could be impacted with the formation of the reduced flow stretch, being trapped in the lagoons formed in this region, as verified in Table 2

Thus, it was possible to identify that more than 153,000 specimens from 183 different species were rescued in the region of the Reduced Flow Excerpt. However, thanks to the execution of the program only 953 had died, and 152,769 copies were recovered with life.

Thus, it is verified that with the decrease of the natural flow of the Xingu river in the ebb period, rescue actions will be necessary in RFS, in order to guarantee the survival of fish possibly trapped in residual pools. With this, there was a significant improvement in the effectiveness of actions to mitigate problems related to ichthyofauna.

\subsection{Changes in fishing patterns}

The flow reduction in the RFS will drastically change the availability of spawning and growth areas of fish populations. Thus, changes in fish populations may result in problems for fishermen, who will have to "learn" from the new conditions to continue fishing. This leads to economic losses resulting from the decrease in income as well as social and political conflicts that will be attributed to the project.

This variation in the fishing pattern can be evidenced in the Belo Monte HPP through the data provided in the monitoring reports of the Sustainable Fishing Incentive Project.

According to the aforementioned project, $92.7 \%$ of the fishermen interviewed are exclusively engaged in catching fish, $2.5 \%$ are exclusively fishing for ornamental fish and $4.8 \%$ catch ornamental and consumer fish, dealing with the two activities, according to the needs and demands.

It is worth noting that in order to analyze the time evolution of production, effort and catch per unit effort (CPUE) by species in the consumption fishery, between the years of 2012 and 2016, 4 species were chosen that stand out in volume of catch in the region: hake, tucunaré, pacu and curimatã, in the stretches closest to the development. Additionally, the evolution of the pupfish fisheries in the stretches below the waterfalls was analyzed, since this is a demand of the fishermen, who accuse decrease in the catches of this important resource.

For the hake species, in the RFS production decreased, despite the increase in effort, with the corresponding negative CPUE trend. For the tucunare species despite the increase in effort, production and CPUE remain stable. For the Pacu species, production and effort showed decreasing or stable trends. For the curimatã species, production and effort showed increasing or stable trends. For the cub / piríba, 
Table 2. Ichthyofauna specimens rescued in the Belo Monte HPP of the Reduced Flow Stretch according to $11^{\text {th }}$ Consolidated Report.

\begin{tabular}{|c|c|c|c|}
\hline Species & Perished & Alive & Grand total \\
\hline Acnodon normani & & 33 & 33 \\
\hline Aequidens michaeli & 21 & 4,472 & 4,493 \\
\hline Aequidens tetramerus & 29 & 12,342 & 12,371 \\
\hline Agoniates halecinus & & 15 & 15 \\
\hline Anchoviella sp, & & 206 & 206 \\
\hline Ancistrus ranunculus & 32 & 311 & 343 \\
\hline Ancistrus sp, & & 39 & 39 \\
\hline Ancistrus sp, “pinta” & 8 & 2,047 & 2,055 \\
\hline Apistogramma sp, & & 282 & 282 \\
\hline Apteronotus albifrons & & 7 & 7 \\
\hline Apteronotus bonapartii & 1 & & 1 \\
\hline Archolaemus janeae & 3 & 192 & 195 \\
\hline Argonectes robertsi & & 262 & 262 \\
\hline Astyanax gr, bimaculatus & 3 & 679 & 682 \\
\hline Astyanax multidens & & 1 & 1 \\
\hline Baryancistrus aff, niveatus & 1 & 41 & 42 \\
\hline Baryancistrus chrysolomus & & 8 & 8 \\
\hline Baryancistrus sp, “verde” & 85 & 70 & 155 \\
\hline Baryancistrus xanthellus & 4 & 73 & 77 \\
\hline Batrochoglanis villosus & & 3 & 3 \\
\hline Bivibranchia fowleri & & 375 & 375 \\
\hline Bivibranchia velox & & 1,679 & 1,679 \\
\hline Boulengerella cuvieri & & 7 & 7 \\
\hline Brachyhypopomus beebei & & 2 & 2 \\
\hline Brycon aff, pesu "adiposa hialina" & 8 & 5,690 & 5,698 \\
\hline Brycon aff, pesu "adiposa preta" & & 116 & 116 \\
\hline Brycon falcatus & & 270 & 270 \\
\hline Bryconamericus orinocoense & & 816 & 816 \\
\hline Bryconops alburnoides & & 1,097 & 1,097 \\
\hline Bryconops caudomaculatus & 5 & 4,788 & 4,793 \\
\hline Bryconops giacopinii & 1 & 37 & 38 \\
\hline Bunocephalus coracoideus & & 1 & 1 \\
\hline Caenotropus labyrinthicus & & 2 & 2 \\
\hline Caquetaia spectabilis & & 521 & 521 \\
\hline Centromochlus heckelii & & 1 & 1 \\
\hline Centromochlus schultzi & & 5 & 5 \\
\hline Cetopsidium sp, & & 6 & 6 \\
\hline Chalceus epakros & & 2 & 2 \\
\hline Characidae spp, & 360 & 57,822 & 58,182 \\
\hline Cichla melaniae & 11 & 1,507 & 1,518 \\
\hline Cichla monoculus & & 101 & 101 \\
\hline Cichla pinima & & 35 & 35 \\
\hline Corydoras cochui & & 248 & 248 \\
\hline Corydoras stenocephalus & & 10 & 10 \\
\hline Creagrutus cracentis & & 1,506 & 1,506 \\
\hline Creagrutus sp, & & 1,070 & 1,070 \\
\hline Crenicichla gr, johanna & & 29 & 29 \\
\hline Crenicichla gr, saxatilis & & 81 & 81 \\
\hline Crenicichla lugubris & 2 & 290 & 292 \\
\hline Crenicichla macrophthalma & & 45 & 45 \\
\hline
\end{tabular}

$\mathrm{HPP}=$ Hydropower Plant. 
Table 2. Continued...

\begin{tabular}{|c|c|c|c|}
\hline Species & Perished & Alive & Grand total \\
\hline Ctenobrycon spilurus & & 30 & 30 \\
\hline Curimata inornata & & 57 & 57 \\
\hline Curimata ocellata & & 1 & 1 \\
\hline Curimatella dorsalis & & 18 & 18 \\
\hline Curimatella immaculata & & 4 & 4 \\
\hline Cyphocharax gouldingi & & 121 & 121 \\
\hline Cyphocharax leucostictus & & 20 & 20 \\
\hline Cyphocharax stilbolepis & & 1 & 1 \\
\hline Eigenmannia aff, trilineata & & 38 & 38 \\
\hline Electrophorus electricus & & 3 & 3 \\
\hline Erythrinus erythrinus & & 1 & 1 \\
\hline Geophagus argyrostictus & & 1,327 & 1,327 \\
\hline Geophagus gr, altifrons & 200 & 7,565 & 7,765 \\
\hline Gymnorhamphichthys sp, & & 3 & 3 \\
\hline Gymnotus carapo & & 3 & 3 \\
\hline Hassar gabiru & & 1 & 1 \\
\hline Hemigrammus ocellifer & & 9 & 9 \\
\hline Hemiodus aff, microlepis & & 79 & 79 \\
\hline Hemiodus sp, “Xingu” & & 404 & 404 \\
\hline Hemiodus tocantinensis & 10 & 1,171 & 1,181 \\
\hline Hemiodus unimaculatus & & 500 & 500 \\
\hline Hemiodus vorderwinckleri & & 61 & 61 \\
\hline Heptapteridae spp, & & 1 & 1 \\
\hline Hoplerythrinus unitaeniatus & & 12 & 12 \\
\hline Hopliancistrus sp, "mancha" & 12 & 122 & 134 \\
\hline Hopliancistrus sp, “pinta” & & 26 & 26 \\
\hline Hoplias aimara & & 180 & 180 \\
\hline Hoplias curupira & 1 & 135 & 136 \\
\hline Hoplias malabaricus & & 354 & 354 \\
\hline Hypancistrus sp,"mancha” & & 1 & 1 \\
\hline Hypoclinemus mentalis & & 2 & 2 \\
\hline Hypomasticus julii & & 54 & 54 \\
\hline Hypoptopoma inexpectatum & 3 & 59 & 62 \\
\hline Hypostomus aff, plecostomus & 11 & 160 & 171 \\
\hline Hypostomus hemicochliodon & & 4 & 4 \\
\hline Imparfinis aff, hasemani & & 10 & 10 \\
\hline Ituglanis sp, & & 22 & 22 \\
\hline Jupiaba acanthogaster & & 353 & 353 \\
\hline Jupiaba polylepis & & 1,875 & 1,875 \\
\hline Knodus heteresthes & & 260 & 260 \\
\hline Knodus savannensis & & 30 & 30 \\
\hline Laemolyta proxima & & 1 & 1 \\
\hline Leporacanthicus heterodon & 2 & 15 & 17 \\
\hline Leporinus aff, fasciatus & 1 & 141 & 142 \\
\hline Leporinus brunneus & & 1 & 1 \\
\hline Leporinus desmotes & & 1 & 1 \\
\hline Leporinus friderici & 1 & 97 & 98 \\
\hline Leporinus maculatus & 1 & 59 & 60 \\
\hline Leporinus multimaculatus & & 11 & 11 \\
\hline Leporinus tigrinus & & 36 & 36 \\
\hline
\end{tabular}

\footnotetext{
HPP $=$ Hydropower Plant.
} 
Table 2. Continued...

\begin{tabular}{|c|c|c|c|}
\hline Species & Perished & Alive & Grand total \\
\hline Leptodoras hasemani & & 1 & 1 \\
\hline Leptorhamdia schultzi & & 14 & 14 \\
\hline Limatulichthys griseus & & 169 & 169 \\
\hline Loricaria birindelli & & 18 & 18 \\
\hline Loricariidae spp, & 3 & & 3 \\
\hline Melanocharacidium dispilomma & & 1 & 1 \\
\hline Mesonauta sp, & 6 & 76 & 82 \\
\hline Metynnis guaporensis & & 31 & 31 \\
\hline Microglanis sp, & & 2 & 2 \\
\hline Microsternarchus bilineatus & & 2 & 2 \\
\hline Moenkhausia celibela & 1 & 530 & 531 \\
\hline Moenkhausia collettii & & 96 & 96 \\
\hline Moenkhausia cotinho & & 356 & 356 \\
\hline Moenkhausia heikoi & & 1,511 & 1,511 \\
\hline Moenkhausia intermedia & & 80 & 80 \\
\hline Moenkhausia lepidura & & 1,071 & 1,071 \\
\hline Moenkhausia loweae & & 42 & 42 \\
\hline Moenkhausia mikia & & 16 & 16 \\
\hline Moenkhausia oligolepis & & 87 & 87 \\
\hline Moenkhausia xinguensis & & 326 & 326 \\
\hline Myleus setiger & 13 & 2,249 & 2,262 \\
\hline Myloplus arnoldi & & 3,353 & 3,353 \\
\hline Myloplus gr, asterias & & 1 & 1 \\
\hline Myloplus rhomboidalis & & 376 & 376 \\
\hline Myloplus rubripinnis & & 890 & 890 \\
\hline Myloplus schomburgkii & 1 & 1,198 & 1,199 \\
\hline Ossubtus xinguense & & 6 & 6 \\
\hline Pachyurus junki & & 10 & 10 \\
\hline Pamphorichthys araguaiensis & & 6,930 & 6,930 \\
\hline Parancistrus aurantiacus & & 3 & 3 \\
\hline Paratrygon aiereba & 1 & 15 & 16 \\
\hline Peckoltia sabaji & 7 & 11 & 18 \\
\hline Peckoltia vittata & 9 & 718 & 727 \\
\hline Phenacogaster gr, pectinatus & & 395 & 395 \\
\hline Phenacorhamdia sp, & & 25 & 25 \\
\hline Pimelodella cristata & & 79 & 79 \\
\hline Pimelodella sp, & & 11 & 11 \\
\hline Pimelodidae spp, & & 1 & 1 \\
\hline Pimelodus ornatus & & 40 & 40 \\
\hline Platydoras armatulus & 1 & 2 & 3 \\
\hline Platydoras sp, “Xingu” & & 9 & 9 \\
\hline Poptella compressa & & 53 & 53 \\
\hline Potamotrygon leopoldi & 6 & 16 & 22 \\
\hline Potamotrygon motoro & 11 & 30 & 41 \\
\hline Potamotrygon orbignyi & 9 & 32 & 41 \\
\hline Prochilodus nigricans & & 41 & 41 \\
\hline Pseudancistrus asurini & 13 & 68 & 81 \\
\hline Pseudoloricaria laeviuscula & & 3 & 3 \\
\hline Pseudopimelodus bufonius & & 25 & 25 \\
\hline Pseudopimelodus pulcher & & 13 & 13 \\
\hline
\end{tabular}

$\mathrm{HPP}=$ Hydropower Plant. 
Table 2. Continued...

\begin{tabular}{|c|c|c|c|}
\hline Species & Perished & Alive & Grand total \\
\hline Pterophyllum scalare & & 14 & 14 \\
\hline Retroculus xinguensis & 4 & 2,011 & 2,015 \\
\hline Rhamdia sp, & & 4 & 4 \\
\hline Rhinodoras boehlkei & & 1 & 1 \\
\hline Rhinopetitia sp, & 1 & 86 & 87 \\
\hline Rineloricaria lanceolata & 7 & 124 & 131 \\
\hline Roeboides affinis & & 27 & 27 \\
\hline Satanoperca aff, jurupari & & 197 & 197 \\
\hline Satanoperca sp, & 2 & 768 & 770 \\
\hline Schizodon vittatus & & 3 & 3 \\
\hline Scobinancistrus aureatus & & 1 & 1 \\
\hline Serrasalmus manueli & & 25 & 25 \\
\hline Serrasalmus rhombeus & & 67 & 67 \\
\hline Spatuloricaria tuira & & 8 & 8 \\
\hline Spectracanthicus punctatissimus & 14 & 593 & 607 \\
\hline Spectracanthicus zuanoni & 6 & 210 & 216 \\
\hline Squaliforma aff, emarginata & & 247 & 247 \\
\hline Sternopygus macrurus & & 128 & 128 \\
\hline Synbranchus lampreia & 2 & 404 & 406 \\
\hline Synbranchus madeirae & 3 & 163 & 166 \\
\hline Synbranchus marmoratus & 5 & 244 & 249 \\
\hline Tatia sp, & & 35 & 35 \\
\hline Teleocichla aff, cinderella & 2 & 1,151 & 1,153 \\
\hline Teleocichla centrarchus & & 766 & 766 \\
\hline Teleocichla gephyrogramma & & 23 & 23 \\
\hline Teleocichla monogramma & & 13 & 13 \\
\hline Teleocichla preta & 8 & 306 & 314 \\
\hline Tetragonopterus chalceus & & 45 & 45 \\
\hline Tocantinsia piresi & 5 & 6 & 11 \\
\hline Tometes ancylorhynchus & & 921 & 921 \\
\hline Tometes kranponhah & 1 & 4,102 & 4,103 \\
\hline Triportheus albus & & 4,328 & 4,328 \\
\hline Triportheus rotundatus & & 35 & 35 \\
\hline Total Geral & 957 & 152,769 & 153,726 \\
\hline
\end{tabular}

HPP $=$ Hydropower Plant.

whose catch is concentrated mainly in the low part of the Xingu river, it is observed that, all the tendencies are slightly negative.

These data indicate that even though there is a decrease in production in relation to previous years, CPUE values are still quite variable, with years with good yields occurring even after the construction of the hydroelectric plant. In the Figure 4 it can be observed that commercial fishery is the most used by the riverside population of the vicinity of the Belo Monte HPP, followed by subsistence commercial fishing. However, in both modalities, a smaller fishing capacity is observed in the section of Reduced Flow (Xingu Voltage - VGX) in relation to the section downstream of the HPP.

However, in order to minimize the impact on the local population, the Ornamental Fish Aquaculture Project was carried out, aiming at the development of protocols for captive maintenance and reproduction of ornamental species, target of extractivism in the region of insertion of the project.

\subsection{Possibility of developing anaerobic conditions}

By reducing the natural flow of the rivers, the water body along the RFS tends to become more stationary. Still waters generally promote strong hypoxia or anoxia in deep layers. This is because the solubility of oxygen in water decreases with the increase in temperature, while decomposition processes that consume oxygen accelerate (Limiar Engenharia Ambiental, 2002).

Preliminary calculations for Curuá-Una show that most of the oxygen enters the reservoir from tributary rivers. Consequently, the size of the anoxic layer and its lifetime 


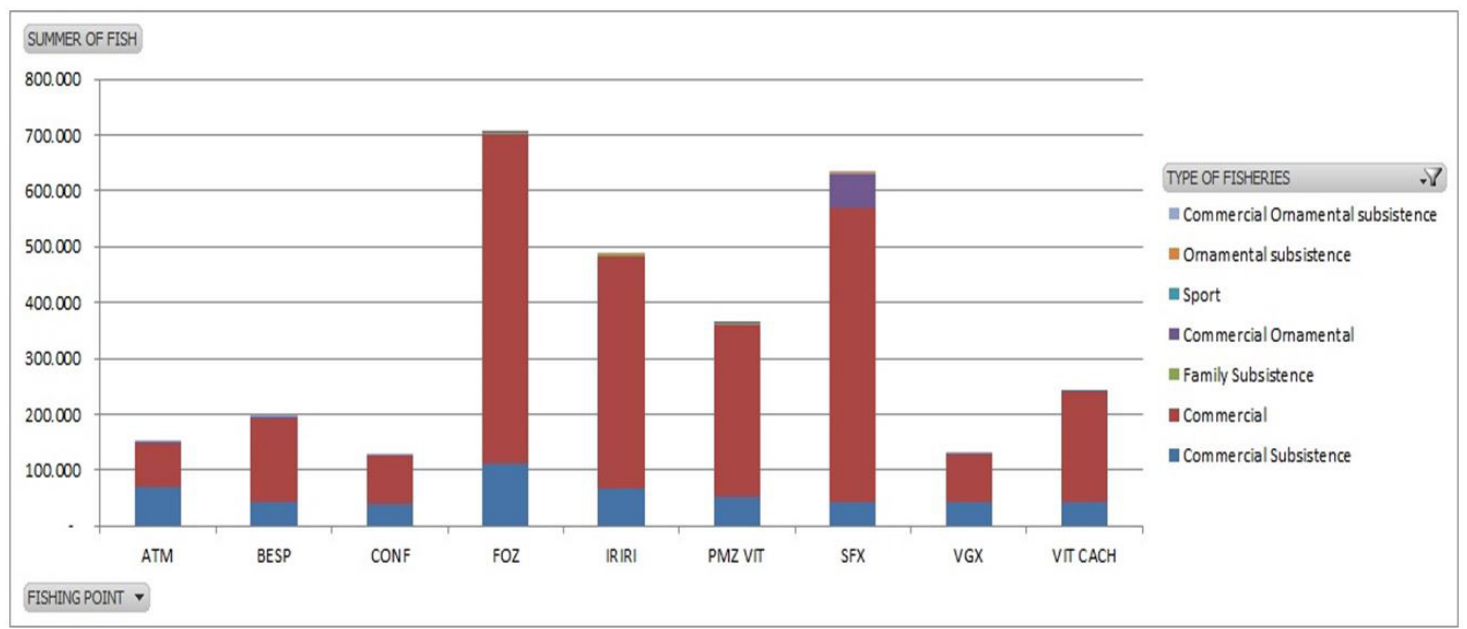

Figure 4. Monitoring of commercial fish production in the Belo Monte HPP. Stretches of the xingu river analyzed: FOZ = mouth of the Xingu River to Porto de Moz; PMZ - VIT = Porto de Moz to Vitoria do Xingu; VIT - CACH = Vitória do Xingu to waterfalls of Belo Monte; VGX = Grand Tour of the Xingu, waterfalls to the Pimentel Site; ATM = Sítio Pimentel to Altamira; BESP = Altamira to the community of Boa Esperança; CONF = Community of Boa Esperança to the mouth of the river Iriri; SFX = Iriri river mouth to São Fidelix do Xingu; IRIRI = Rio Iriri to Vila de Maribel.

are strongly influenced by the water retention time in the reservoir (Heide, 1982).

Using data from Belo Monte HPP as a base, it can be verified that there is a rise in water temperature in 2007 , when the Environmental Impact Study was carried out to monitor water quality, between 2012 and 2016 (Table 3).

The elevation of the water temperature, within certain limits, increases the metabolic activity of fish and bacteria, causing greater consumption of oxygen and thus doubling aquatic aerobic respiration (Branco, 1978). In addition, raising the temperature can cause an increase in the toxic action of many elements and chemical compounds in water

Concomitant to the increase in temperature it is possible to observe a decrease in the levels of dissolved oxygen due to decomposition processes that consume oxygen accelerate (Table 4). From the ecological point of view, dissolved oxygen is an extremely important parameter as it is necessary for the respiration of most organisms that inhabit the aquatic environment. Generally, dissolved oxygen decreases or disappears when the water receives large quantities of biodegradable organic substances found, for example, in domestic sewage, certain industrial waste, vinasse, and others. Another example is organic waste dumped into bodies of water that are decomposed by 39 microorganisms that use oxygen in respiration. Thus, the higher the organic matter load, the greater the number of decomposing microorganisms and, consequently, the greater the oxygen consumption.

\subsection{Changes in coliform levels}

The increase in the concentration of coliforms is related to the increase in the concentration of nutrients, particularly nitrogen and phosphorus, due to untreated wastewater. Water quality and water uses along the stretch may be affected, increasing the potential for the transmission of waterborne diseases since coliforms are indicators only of faecal contamination and consume more oxygen due to the decomposition of organic matter.

Faecal coliforms, specifically Escherichia coli, are commonly regarded as a water quality parameter. It indicates contamination by sewage or animal waste harmful to human health. Total coliforms can be found naturally in the soil. They are not a specific determinant of water contamination indicators. Human populations that lack adequate sewage treatment increase nutrient loads and contribute to the spread of waterborne diseases. Together with flow reduction in RFS, higher sewage loads result in a higher concentration of coliforms.

For Belo Monte HPP, it can be observed through the water quality analysis - carried out in 2007 when the Environmental Impact Study - and the 12th Consolidated Report - executed between 2012 and 2016 - that, as expected, there is an increase in values for the Reduced Flow Stretch (Table 5).

Based on the analyzed data, it was verified that in all the analyzed periods - flood, outflow, dry and full - there was an increase in the levels of coliform in the Excerpt in question, reaching up to $4609 \%$ as verified in the RX04 point in the ebb period

\subsection{Decrease in aeration capacity}

An impact of the change in regimes concerns the decrease in the water re-oxygenation capacity (Albizuri and Bianco, 1997). The reaeration coefficient is proportional to water turbulence and water viscosity. Turbulence depends on wind speed and the action of waves. Viscosity is a function of water temperature (Arceivala, 1981).

With the buffer, there is a decrease in water flow rates and thus a decrease in water turbulence, which results in low reaeration coefficients. Similarly, changes in the 
Table 3. Comparative analysis of the water temperature in the Reduced Flow Stretch of the Belo Monte HPP.

\begin{tabular}{|c|c|c|c|c|c|c|c|}
\hline Period & Local & 2007 & 2012 & 2013 & 2014 & 2015 & 2016 \\
\hline \multirow[t]{8}{*}{ Flood } & RESSACA & n.d. & 30.9 & 29.0 & 28.6 & 29.6 & 29.4 \\
\hline & FAZENDA & n.d. & 30.7 & 29.4 & 28.6 & 29.7 & 29.8 \\
\hline & RX04 & 30.5 & 31.0 & 29.3 & 28.4 & 29.6 & 26.6 \\
\hline & RX20 & n.d. & 31.4 & 29.5 & 28.2 & 29.4 & 29.3 \\
\hline & RX05 & 30.0 & 30.6 & 29.0 & 27.9 & 29.1 & 29.4 \\
\hline & RX06 & 30.1 & 31.9 & 27.8 & 27.6 & 29.2 & 29.4 \\
\hline & RX21 & n.d. & 31.2 & 29.5 & 30.9 & 31.3 & 29.0 \\
\hline & RX17 & 30.5 & 31.4 & 29.2 & 28.9 & 29.3 & 29.9 \\
\hline \multirow[t]{8}{*}{ Outflow } & RESSACA & n.d. & 31.2 & 29.6 & 30.2 & 30.5 & 30.2 \\
\hline & FAZENDA & n.d. & 30.9 & 29.8 & 30.3 & 30.7 & 30.5 \\
\hline & RX04 & 30.2 & 30.8 & 29.9 & 30.4 & 30.4 & 31.0 \\
\hline & RX20 & 29.9 & 30.8 & 30.9 & 30.4 & 30.4 & 30.3 \\
\hline & RX05 & 29.8 & 30.6 & 30.3 & 30.1 & 29.8 & 30.5 \\
\hline & RX06 & 29.7 & 30.3 & 28.4 & 28.9 & 30.2 & 30.7 \\
\hline & RX21 & n.d. & 30.5 & 30.8 & 29.7 & 31.0 & 32.4 \\
\hline & RX17 & 30.4 & 30.3 & 29.2 & 30.5 & 30.1 & 31.0 \\
\hline \multirow[t]{8}{*}{ Dry } & RESSACA & 30.5 & 30.1 & 31.2 & 30.9 & 29.5 & 30.6 \\
\hline & FAZENDA & 30.6 & 30.2 & 31.2 & 30.9 & 29.6 & 30.9 \\
\hline & RX04 & 31.0 & 30.5 & 31.3 & 31.3 & 29.8 & 32.4 \\
\hline & RX20 & 30.5 & 31.6 & 30.6 & 30.5 & 30.3 & 31.7 \\
\hline & RX05 & 30.3 & 30.7 & 31.1 & 30.7 & 29.6 & 31.6 \\
\hline & RX06 & 30.1 & 31.3 & 31.8 & 30.0 & 29.9 & 32.0 \\
\hline & RX21 & 31.6 & 29.9 & 31.8 & 31.1 & 31.6 & 33.4 \\
\hline & RX17 & 32.1 & 31.7 & 31.4 & 31.1 & 30.0 & 31.3 \\
\hline \multirow[t]{8}{*}{ Full } & RESSACA & 27.1 & 27.7 & 29.0 & 27.9 & 28.6 & 29.0 \\
\hline & FAZENDA & 27.6 & 27.7 & 29.0 & 27.8 & 28.5 & 28.9 \\
\hline & RX04 & 27.8 & 27.7 & 29.0 & 27.8 & 28.5 & 29.1 \\
\hline & RX20 & 26.8 & 27.5 & 28.8 & 27.5 & 28.7 & 29.2 \\
\hline & RX05 & 27.1 & 27.9 & 28.6 & 27.7 & 28.8 & 29.0 \\
\hline & RX06 & 26.9 & 27.9 & 28.7 & 26.0 & 28.8 & 28.1 \\
\hline & $\mathrm{RX} 21$ & n.d. & 28.9 & 29.8 & 28.1 & 29.4 & 29.2 \\
\hline & RX17 & 27.7 & 28.0 & 28.9 & 27.7 & 28.8 & 28.8 \\
\hline
\end{tabular}

$\mathrm{HPP}=$ Hydropower Plant.

hydrological pulse along the RFS lead to more favourable conditions for the growth of algae. If intense, the growth of algae leads to eutrophication. In addition, flow reductions in such an anastomosed stretch form still water channels, which will only be renewed during periods of greater floods at high temperatures.

In this sense, food chains in most aquatic ecosystems, especially in the Neotropics, are likely to be dominated by a generalist and opportunistic macroinvertebrate rate that occupies simultaneously more than one trophic category (Tomanova et al., 2006). Feeding by filtering insects, for example, is not restricted to the retention of the fine particulate organic matter that passes through its filtration nets. Organisms belonging to this trophic guild, while favored by the flow of water, may employ alternative methods of particle capture (eg, direct trapping or electrostatic attraction) that are important, especially under low current conditions (Wallace and Merritt, 1980).
In relation to total density, higher value was recorded in the semi-lentic phase. Increased numbers of individuals / m2 in reduced flow streams occurs when organisms are concentrated in the residual pools, facilitating sampling (Cortes et al., 2002; Dewson et al., 2007b). In this sense we can observe in the data of beautiful mount that in the section of reduced flow there was a considerable increase of macroinvertebrates, as can be observed in Figure 5 .

\subsection{Interruption of economic activity with the consumptive use of water}

One of the identified impacts of the reduction in natural flows for the human environment is the decrease in water available to land owners or those who capture water located along reduced flow stretches.

The consumptive use of water affects the input flow rates of hydropower plants. A consumptive use is the extraction of water for a purpose that will incorporate it 
Table 4. Comparative analysis of the parameter Dissolved Oxygen in the Section of Reduced Flow Stretch of HPP Belo Monte.

\begin{tabular}{|c|c|c|c|c|c|c|c|}
\hline Period & Local & 2007 & 2012 & 2013 & 2014 & 2015 & 2016 \\
\hline \multirow[t]{8}{*}{ Flood } & RESSACA & n.d. & 6.41 & 6.92 & 6.94 & 7.29 & 6.96 \\
\hline & FAZENDA & n.d. & 6.34 & 7.13 & 7.03 & 7.33 & 6.85 \\
\hline & RX04 & 7.7 & 6.54 & 7.05 & 6.97 & 7.22 & 7.34 \\
\hline & RX20 & n.d. & 6.86 & 7.42 & 7 & 7.37 & 7.39 \\
\hline & RX05 & 7.53 & 6.14 & 6.97 & 7.07 & 7.12 & 7.19 \\
\hline & RX06 & 7.47 & 7.25 & 6.53 & 6.32 & 7.06 & 7.31 \\
\hline & $\mathrm{RX} 21$ & n.d. & 7.17 & 7.25 & 7.4 & 7.7 & 7.6 \\
\hline & RX17 & 8.39 & 7.97 & 7.8 & 7.17 & 7.96 & 7.95 \\
\hline \multirow[t]{8}{*}{ Outflow } & RESSACA & n.d. & 7.19 & 6.16 & 7.14 & 7.58 & 6.6 \\
\hline & FAZENDA & n.d. & 7.38 & 6.32 & 7.24 & 7.67 & 6.59 \\
\hline & RX04 & 8.05 & 7.38 & 6.36 & 7.14 & 7.58 & 6.82 \\
\hline & RX20 & 8.1 & 7.38 & 6.68 & 7.55 & 7.46 & 6.67 \\
\hline & RX05 & 8.07 & 7.22 & 6.42 & 7.12 & 7.17 & 6.8 \\
\hline & RX06 & 8.13 & 7.09 & 6.28 & 7 & 7.73 & 8.23 \\
\hline & $\mathrm{RX} 21$ & n.d. & 7.32 & 6.4 & 7.16 & 7.33 & 8.16 \\
\hline & RX17 & 8.94 & 7.5 & 7.45 & 7.52 & 8.24 & 7.56 \\
\hline \multirow[t]{8}{*}{ Dry } & RESSACA & 7.06 & 7.05 & 7.24 & 7.31 & 6.96 & 21.81 \\
\hline & FAZENDA & 7.03 & 6.95 & 7.05 & 7.38 & 6.97 & 21.56 \\
\hline & RX04 & 7.16 & 7.21 & 7.25 & 7.31 & 7.21 & 15.76 \\
\hline & RX20 & 7.5 & 7.68 & 6.89 & 7.11 & 7.61 & 14.75 \\
\hline & RX05 & 7.27 & 7.22 & 6.83 & 7.05 & 7.06 & 14.57 \\
\hline & RX06 & 7.42 & 7.49 & 7.33 & 7.39 & 7.36 & 7.35 \\
\hline & $\mathrm{RX} 21$ & 7.15 & 7.51 & 7.36 & 7.5 & 7.3 & 5.32 \\
\hline & RX17 & 7.6 & 7.8 & 7.64 & 7.82 & 7.8 & 20.47 \\
\hline \multirow[t]{8}{*}{ Full } & RESSACA & 5.63 & 6.62 & 5.8 & 5.35 & 5.1 & 6.73 \\
\hline & FAZENDA & 6.34 & 6.78 & 5.99 & 5.65 & 6.71 & 7.12 \\
\hline & RX04 & 7.07 & 6.85 & 6.03 & 5.62 & 6.22 & 7.16 \\
\hline & RX20 & 6.05 & 6.63 & 5.72 & 5.5 & 6.2 & 6.1 \\
\hline & RX05 & 5.75 & 6.86 & 5.4 & 5.15 & 6.22 & 6.27 \\
\hline & RX06 & 6.56 & 6.88 & 5.75 & 5.01 & 6.18 & 5 \\
\hline & $\mathrm{RX} 21$ & n.d. & 7.7 & 6.84 & 0.86 & 6.8 & 7.39 \\
\hline & RX17 & 7.35 & 6.93 & 6.76 & 6.85 & 7.83 & 6.84 \\
\hline
\end{tabular}

n.d = undefined; HPP = Hydropower Plant.

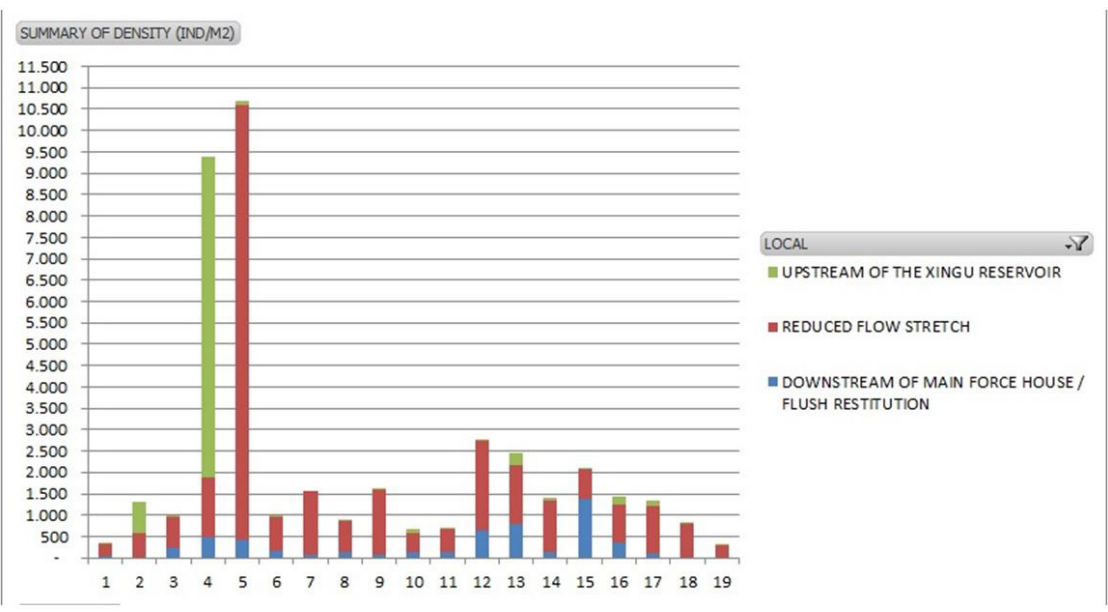

Figure 5. Monitoring of macroinvertebrates in the section of Reduced Flow Stretch of Belo Monte HPP. HPP $=$ Hydropower Plant. 
Table 5. Comparative analysis of thermotolerant coliforms in the Reduced Flow Stretch of Belo Monte HPP.

\begin{tabular}{|c|c|c|c|c|c|c|c|}
\hline Period & Local & 2007 & 2012 & 2013 & 2014 & 2015 & 2016 \\
\hline \multirow[t]{8}{*}{ Flood } & RESSACA & n.d. & 2.359 & 5.510 & 294 & 4.106 & 2.260 \\
\hline & FAZENDA & n.d. & 2.143 & 3.058 & 647 & 2.851 & 1.042 \\
\hline & RX04 & 12098.0 & 1.664 & 2.708 & 247 & 4.884 & 1.980 \\
\hline & RX20 & n.d. & 3.873 & 5.400 & 254 & 1.437 & 3.248 \\
\hline & RX05 & 12098.0 & 2.187 & 3.348 & 307 & 4.352 & 2.592 \\
\hline & RX06 & 12098.0 & 5.172 & 1.918 & 710 & 1.437 & 5.226 \\
\hline & $\mathrm{RX} 21$ & n.d. & 2.481 & 22.398 & 0 & 9.804 & 2.338 \\
\hline & RX17 & 12098.0 & 2.481 & 3.058 & 111 & 4.350 & 1.262 \\
\hline \multirow[t]{8}{*}{ Outflow } & RESSACA & n.d. & 2.723 & 2.592 & 52 & 15.531 & 1.124 \\
\hline & FAZENDA & n.d. & 6.867 & 2.402 & 233 & 3.968 & 1.137 \\
\hline & RX04 & 188.0 & 7.270 & 1.852 & 1.230 & 8.664 & 1.515 \\
\hline & RX20 & 4611.0 & 4.106 & 4.028 & 2.809 & 12.033 & 5.172 \\
\hline & RX05 & 190.0 & 4.884 & 11.472 & 2.851 & 2.504 & 2.143 \\
\hline & RX06 & 250.0 & 5.794 & 7.125 & 193 & 8.164 & 19.863 \\
\hline & RX21 & n.d. & 2.489 & 2.118 & 2.132 & 9.804 & 14.136 \\
\hline & RX17 & 1214.0 & 4.884 & 2.187 & 210 & 10.462 & 805 \\
\hline \multirow[t]{8}{*}{ Dry } & RESSACA & 1954.0 & 880 & 928 & 1.816 & 2.446 & 1.956 \\
\hline & FAZENDA & 1788.0 & 1.470 & 3.684 & 486 & 1.236 & 1.112 \\
\hline & RX04 & 1580.0 & 2.247 & 518 & 808 & 2.145 & 1.382 \\
\hline & $\mathrm{RX} 20$ & 1040.0 & 1.565 & 1.974 & 1.008 & 2.023 & 4.028 \\
\hline & RX05 & 6867.0 & 1.565 & 12.976 & 790 & 3.227 & 4.494 \\
\hline & RX06 & 1478.0 & 2.282 & 1.204 & 12.976 & 1.453 & 3.912 \\
\hline & RX21 & 422.0 & 4.106 & 39.726 & 700 & 3.700 & 3.654 \\
\hline & RX17 & 440.0 & 2.382 & 1.416 & 958 & 1.128 & 1.430 \\
\hline \multirow[t]{8}{*}{ Full } & RESSACA & n.d. & 5.974 & 8.720 & 2.708 & 0 & 5.172 \\
\hline & FAZENDA & $>4839.2$ & 4.718 & 3.034 & 3.170 & 921 & 6.867 \\
\hline & RX04 & n.d. & 4.063 & 3.550 & 2.260 & 0 & 1.565 \\
\hline & RX20 & n.d. & 4.718 & 1.918 & 1.868 & 663 & 2.282 \\
\hline & RX05 & n.d. & 5.335 & 8.212 & 4.978 & 1.134 & 4.611 \\
\hline & RX06 & n.d. & 4.658 & 3.564 & 3.586 & 773 & 4.884 \\
\hline & $\mathrm{RX} 21$ & n.d. & 4.128 & 5.446 & 34.658 & 1.553 & 0 \\
\hline & RX17 & n.d. & 6.325 & 8.212 & 15.402 & 0 & 3.076 \\
\hline
\end{tabular}

n.d = undefined; HPP = Hydropower Plant.

partially (part of what is extracted is later returned) or totally (all that is extracted is incorporated) (Maia et al., 2011).

There are many water uses that are considered consumptive. They are relevant because they mean a large volume of water is consumed. In Brazil, similar to what occurs in other countries, the highest water consumption is mainly concentrated in agriculture, particularly crop irrigation. Household use is the second largest water consumer, with approximately $20 \%$ of the total demand, followed by industry and livestock (Freitas, 2012).

In the case of the Belo Monte HPP, one of the consumptive uses affected by the Reduced Flow Stretch is the garimpo activity. According to the Basic Environmental Project (PBA) of the Belo Monte Hydroelectric Power Plant, the activities of the Project for Monitoring the Garimpeira Activity - PMAG have the objective of monitoring the activity of gold mining in the region of Volta Grande do $\mathrm{Xingu}$, in the form of garimpos, and its dynamics along the construction and operation stages of the hydroelectric project on-screen, covering the portions of the directly affected (ADA) and direct influence areas (AID) of the Belo Monte HPP, corresponding respectively to the Xingu river channel in the stretch that will suffer reduction of flow - RFS (and its natural area of permanent preservation) and in its surroundings (on the right bank), where, occasionally, there is mining activity.

Still, in addition to consumptive uses, non-consumptive uses, including leisure and recreation, which also require large volumes of water, may be affected by this reduction in the flow of river stretches.

\subsection{River silting}

The reduction in currents, resulting from a reduction in flows in the RFS, may interfere with downstream silting, as this may result in erosion of margins in addition to increasing erosion in valleys until a new balance determined 
by the river's hydraulic geometry is reached (Junk and Mello, 1990).

\section{Conclusions}

The natural fluctuation of the flow of a river increases the diversity of habitats and maintains the richness and complexity of biological communities. According to Connell (1978), species diversity is at its highest at an intermediate level of disturbance, which can be caused by the natural fluctuation of river flows. However, the flux created by the operation of a hydropower plant designed to meet energy demands does not present the same intensity and unpredictability (Poff et al., 1997). This leads to the destabilization of biological communities and the loss of biodiversity. In addition, changes in the river hydrograph may cause serious interference in the survival of communities that depend largely on fishing.

Currently, a notable problem for the management of water resources is the conflict between the protection of aquatic organisms' habitats and the increasing demand for the use of water in rivers (Sarmento, 2007). Water plays valuable roles for living beings, such as the maintenance of public health, economic development, recreation and the preservation of ecological balance. The services provided by water depend on the maintenance of its hydrological, morphological, chemical and ecological characteristics (Benetti et al., 2003).

According to these authors, one of the variables required to enable the continuity of ecosystem functions of aquatic environments impacted by the use of water resources is maintaining the flows known as "ecological flows"; despite being less voluminous than natural flows, they ensure the persistence of the functional and structural processes of the aquatic ecosystem. Thus, the determination of the ecological flow is a strategy to minimize the impacts of various water uses on aquatic resources.

However, the definition of remaining flow in reduced flow stretches or even downstream from hydropower plants without reservoirs should not be an exercise of flow parametrization only but should be an analysis of multiple water uses that meet health, ecological and other water use demands according to the characteristics of each site (Santos et al., 2003).

\section{References}

ALBIZURI, R.G. and BIANCO, C., 1997. A qualidade da água em reservatórios do setor elétrico. In: Anais do Simpósio Brasileiro de Recursos Hídricos, 1997, Vitória, ES, Brasil. Porto Alegre: ABRH, pp. 12.

ARAÚJO, F.G., 1998. Adaptação do índice de integridade biótica usando a comunidade de peixes para o rio Paraíba do sul. Revista Brasileira de Biologia, vol. 58, no. 4, pp. 547-558. http://dx.doi. org/10.1590/S0034-71081998000400002.

ARCEIVALA, S.J., 1981. Wastewater treatment and disposal: engineering and ecology in pollution control. New York: Marcel Dekker.
ASSOCIAÇÃO BRASILEIRA DE NORMAS TÉCNICAS - ABNT. 2004. NBR ISO 14001: sistemas de gestão ambiental: requisitos com orientação para uso. Rio de Janeiro: ABNT.

BAXTER, R.M., 1977. Environmental effects of dams and impoundments. Annual Review of Ecology and Systematics, vol. 8, no. 1, pp. 255-283. http://dx.doi.org/10.1146/annurev. es.08.110177.001351.

BENETTI, A.D., LANNA, A.E. and COBALCHINI, M.S., 2003. Metodologias para determinação de vazões ecológicas em rios. Revista Brasileira de Recursos Hídricos, vol. 8, no. 2, pp. 149-160. http://dx.doi.org/10.21168/rbrh.v8n2.p149-160.

BIZERRIL, C.R.F. and FONSECA, M.C.G., 2002. Programa de desenvolvimento de pesquisas científicas no trecho de vazão reduzida. Belo Horizonte: CEMIG, 26 p. Plano de Controle Ambiental, Doc. 8648/C1-6B-RL-3402-0.

BOLEA, M.T.E., 1989. Evaluacion del impacto ambiental. 2nd ed. Madri: Fundación MAPFRE, 609 p.

BRANCO, S.M., 1978. Hidrobiologia aplicada à engenharia sanitária. São Paulo, CETESB, 620 p.

BRASIL. Conselho Nacional do Meio Ambiente - CONAMA, 1986. Resolução CONAMA ${ }^{\circ} 1$ de 23 de janeiro de 1986. Dispõe sobre o licenciamento ambiental e o estudo prévio de impacto ambiental. Diário Oficial da República Federativa do Brasil, Brasília, 17 fev.

BRASIL. Conselho Nacional do Meio Ambiente - CONAMA, 2005. Resolução CONAMA $n^{\circ} 357$ de 17 de março de 2005. Dispõe sobre a classificação dos corpos d'água e diretrizes ambientais para o seu enquadramento, bem como estabelece as condições e padrões de lançamento de efluentes, e dá outras providências. Diário Oficial da República Federativa do Brasil, Brasilia, 18 mar.

BRASIL. Ministério de Minas e Energia - MME. Empresa de Pesquisa Energética - EPE, 2007. Plano Nacional de Energia 2030. Rio de Janeiro: EPE, 408 p.

BRITO, R.P., 2009. Limitações do Critério de Vazão Ecológica do Estado do Tocantins: o caso das PCHs Agratrafo e Palmeiras. Porto Alegre: Universidade Federal do Rio Grande do Sul, 94 p. Dissertação de Mestrado em Recursos Hídricos e Saneamento Ambiental.

CAMPOS, J.N.B., VIEIRA NETO, J.F. and MARTINS, E.S., 1997. Vulnerabilidade de sistemas hídricos: um estudo de caso. Revista Brasileira de Recursos Hídricos, vol. 2, no. 2, pp. 21-44.

CAZAUBON, A. and GIUDICELLI, J., 1999. Impact of the residual flow on the physical characteristics and benthic community (algae, invertebrates) of a regulated Mediterranean river: The Durance, France. Regulated Rivers: Research and Management, vol. 15, no. 5, pp. 441-461. http://dx.doi.org/10.1002/(SICI)10991646(199909/10)15:5<441::AID-RRR558>3.0.CO;2-9

CONNELL, J., 1978. Diversity in tropical rain forest and coral reefs. Science, vol. 199, no. 4335, pp. 1302-1310. http://dx.doi. org/10.1126/science.199.4335.1302. PMid:17840770.

CORTES, R.M.V., FERREIRA, M.T., OLIVEIRA, S.V. and OLIVEIRA, D., 2002. Macroinvertebrate community structure in a regulated river segment with different flow conditions. River Research and Applications, vol. 18, no. 4, pp. 367-382. http:// dx.doi.org/10.1002/rra.679.

COVICH, A.P., AUSTEN, M.C., BÄRLOCHER, F., CHAUVET, E., CARDINALE, B.J., BILES, C.L., INCHAUSTI, P., DANGLES, O., SOLAN, M., GESSNER, M.O., STATZNER, B. and MOSS, 
B., 2004. The role of biodiversity in the functioning of fresh water and marine benthic ecosystems. Bioscience, vol. 54, no. 8, pp. 767-775. http://dx.doi.org/10.1641/0006-3568(2004)054[0767:TR OBIT]2.0.CO;2.

DEWSON, Z.S., JAMES, A.B.W. and DEATH, R.G., 2007a. A review of the consequences of decreased flow for instream habitat and macroinvertebrates. Journal of the North American Benthological Society, vol. 26, no. 3, pp. 401-415. http://dx.doi. org/10.1899/06-110.1.

DEWSON, Z.S., JAMES, A.B.W. and DEATH, R.G., 2007b. Invertebrate community responses to experimentally reduced discharge in small streams of different water quality. Journal of the North American Benthological Society, vol. 26, no. 4, pp. 754-766. http://dx.doi.org/10.1899/07-003R.1.

EMPRESA DE PESQUISA ENERGÉTICA-EPE, 2016. Balanço Energético Nacional 2016: ano base 2015. Rio de Janeiro: EPE.

ENGEVIX, 2002. Programa de Garantia das Condições Hidrológicas e Ambientais no Trecho de Vazão Reduzida, Plano de Controle Ambiental: Capim Branco I. Minas Gerais.

FARIA, F.A.M., 2011. Metodologia de prospecção de pequenas centrais hidrelétricas. São Paulo: Universidade de São Paulo, 212 p. Dissertação de Mestrado em Engenharia Hidráulica e Sanitária. http://dx.doi.org/10.11606/D.3.2011.tde-01062011-125528.

FARIAS, R.A.N., 2014. Avaliação dos procedimentos de autorização e outorga para implantação de pequenas centrais hidrelétricas. Brasília: Universidade de Brasília, 274 p. Dissertação de Mestrado em Tecnologia Ambiental e Recursos Hídricos.

FERRAREZE, M., NOGUEIRA, M.G. and CASATTI, L., 2015. Differences in ichthyofauna feeding habits among lateral lagoons and the river channel in a large reservoir. Brazilian Journal of Biology $=$ Revista Brasileira de Biologia, vol. 75, no. 2, pp. 380390. http://dx.doi.org/10.1590/1519-6984.14713. PMid:26132022.

FLAUSINO-JUNIOR, N., 2008. Ictiofauna associada a bancos de Podostemaceae no complexo de Cachoeiras de Dardanelos, Rio Aripuanã - MT. Manaus: Instituto Nacional de Pesquisas da Amazônia, 59 p. Dissertação de Mestrado em Ciências Biológicas.

FREITAS, S.P., 2012. O impacto do uso e consumo de água na mineração sobre o bloco de energia assegurada em empreendimentos hidrogeradores: estudo de caso da PCH Bicas. Belo Horizonte: Universidade Federal de Minas Gerais, 113 p. Dissertação de Mestrado em Saneamento, Meio Ambiente e Recursos Hídricos.

GRAÇA, M.A.S., 2001. The role of invertebrates on leaf litter decomposition in stream - a review. International Review of Hydrobiology, vol. 86, no. 4-5, pp. 383-393. http:// dx.doi.org/10.1002/1522-2632(200107)86:4/5<383::AIDIROH383>3.0.CO;2-D.

HEIDE, J.V.D., 1982. Lake Brokopondo: filling phase limnology of a man-made lake in the humid tropics. Amsterdam: University of Amsterdam, $428 \mathrm{p}$.

JUNK, W.J. and MELLO, J.A.S.N., 1990. Impactos ecológicos das represas hidrelétricas na bacia amazônica brasileira. Estudos Avançados, vol. 4, no. 8, pp. 126-143. http://dx.doi.org/10.1590/ S0103-40141990000100010.

KINZIE, R.A., CHONG, C., DEVRELL, J., LINDSTROM, D. and WOLFF, R.H., 2006. Effects of water removal on a Hawaiian stream ecosystem. Pacific Science, vol. 60, no. 1, pp. 1-47. http:// dx.doi.org/10.1353/psc.2005.0058.
LIMIAR ENGENHARIAAMBIENTAL, 2002. Estudo de Impacto Ambiental (EIA) da PCH Tombo. Belo Horizonte: Limiar.

MAIA, G. A R., ZAMBON, R.C. and BARROS, M.T.L., 2011. Otimização da operação de pequenas centrais hidrelétricas. In: Anais do XIX Simpósio Brasileiro de Recursos Hídrico, 2011, Maceió, AL, Brasil. Porto Alegre: ABRH.

MCINTOSH, M.D., BENBOW, M.E. and BURKY, A.J., 2002. Effects of stream diversion on riffle macroinvertebrate communities in a Maui, Hawaii, stream. River Research and Applications, vol. 18, no. 6, pp. 569-581. http://dx.doi.org/10.1002/rra.694

MOREIRA, A. C., 1999. Megaprojetos e ambiente urbano: Parâmetros para elaboração do relatório de impacto de vizinhança. São Paulo: FAUUSP.

MORTARI, D., 1997. Uma abordagem geral sobre a vazão remanescente, em trechos "curtocircuitados", de usinas hidrelétricas. In: Anais do XII Simpósio Brasileiro de Recursos Hidricos, 1997 , Vitória, ES, Brasil. Porto Alegre: ABRH.

MÜLLER, A.C., 1995. Hidrelétricas, meio ambiente e desenvolvimento. São Paulo: Makron Books.

NOGUEIRA, V.P.Q., 1991. Qualidade da água em lagos e reservatórios. In: R.L. PORTO, ed. Hidrologia ambiental. São Paulo: Universidade de São Paulo. Coleção ABRH de Recursos Hídricos, vol. 3.

PHILBRICK, C.T. and NOVELO, R.A., 1995. New World Podostemaceae: ecological and evolutionary enigmas. Brittonia, vol. 47, no. 2, pp. 210-222. http://dx.doi.org/10.2307/2806959.

PHILBRICK, C.T. and NOVELO, R.A., 1998. Flowering phenology, pollen floow, and seed production in Marathrum rubrum (Podostemaceae). -. Aquatic Botany, vol. 62, no. 3, pp. 199-206. http://dx.doi.org/10.1016/S0304-3770(98)00090-4.

POFF, N.L., ALLAN, J.D., BAIN, M.B., KARR, J.R., PRESTEGAARD, K.L., RICHTER, B.D., SPARKS, R.E. and STROMBERG, J.C., 1997. The Natural Flow Regime. A paradigm for river conservation and restoration. Bioscience, vol. 47, no. 11, pp. 769-784. http://dx.doi.org/10.2307/1313099.

POFF, N.L., RICHTER, B.D., ARTHINGTON, A.H., BUNN, S.E., NAIMAN, R.J., KENDY, E., ACREMAN, M., APSE, C., BLEDSOE, B.P., FREEMAN, M.C., HENRIKSEN, J., JACOBSON, R.B., KENNEN, J.G., MERRITT, D.M., O'KEEFFE, J.H., OLDEN, J.D., RODGERS, K., THARME, R.E. and WARNER, A., 2010. The ecological limits of hydrologic alteration (ELOHA): a new framework for developing regional environmental flow standards. Freshwater Biology, vol. 55, pp. 147-170. http://dx.doi.org/10.1111/j.1365-2427.2009.02204.x.

SÁNCHEZ, L.E., 2008. Avaliação de impacto ambiental: conceitos e métodos. São Paulo: Oficina de Textos, 495 p

SANTOS, A.H.M., RIBEIRO JÚNIOR, L.U., GARCIA, M.A.R.A. and SEVERI, M.A., 2003. Vazão remanescente no trecho de vazão reduzida de pequenas centrais hidrelétricas. In: Anais do Simpósio do XV Simpósio Brasileiro de Recursos Hídricos, 2003, Curitiba, PR, Brasil. Porto Alegre: ABRH.

SARMENTO, R., 2007. Estado da arte da vazão ecológica no Brasil e no mundo: produto 2. Belo Horizonte: UNESCO/ANA/ CBHSF, 38 p. Relatório Projeto 704BRA2041.

SCHORK, G. and ZANIBONI-FILHO, E., 2017. Structure dynamics of a fish community over ten years of formation in the reservoir of the hydroelectric power plant in upper Uruguay River. Brazilian Journal of Biology $=$ Revista Brasileira de Biologia, 
vol. 77, no. 4, pp. 710-723. http://dx.doi.org/10.1590/15196984.17015. PMid:28562786.

SOUZA, C.F., 2009. Vazões ambientais em hidrelétricas: Belo Monte e Manso. Porto Alegre: Universidade Federal do Rio Grande do Sul, 163 p. Tese de Doutorado em Recursos Hídricos e Saneamento Ambiental.

TOMANOVA, S., GOITIA, E. and HELESIC, J., 2006. Trophic levels and functional feeding groups of macroinvertebrates in neotropical streams. Hydrobiologia, vol. 556, no. 1, pp. 251-264. http://dx.doi.org/10.1007/s10750-005-1255-5.

TUCCI, C.E.M., 2012 [viewed 10 October 2015]. Blog do Tucci: trecho de vazão reduzida: conceitos [online]. Porto Alegre: RHAMA. Available from: http://rhama.net/wordpress/?p=307

VANNOTE, R.L., MINSHALL, J.V., CUMMINS, K.W., SEDELL, J.R. and CUSHING, C.E., 1980. The river continuum concept. Canadian Journal of Fisheries and Aquatic Sciences, vol. 37, no. 1, pp. 130-137. http://dx.doi.org/10.1139/f80-017.

WALLACE, J.B. and MERRITT, R.W., 1980. Filter-feeding ecology of aquatic insects. Annual Review of Entomology, vol. 25 , no. 1, pp. 103-132. http://dx.doi.org/10.1146/annurev. en.25.010180.000535.

WALLACE, J.B. and WEBSTER, J.R., 1996. The role of macroinvertebrates in stream ecosystem function. Annual Review of Entomology, vol. 41, no. 1, pp. 115-139. http://dx.doi.org/10.1146/ annurev.en.41.010196.000555. PMid:15012327.

WELCOMME, R.L., 1992. Pesca fluvial. Roma: FAO, 303 p. FAO Documento Técnico sobre as Pescas, no. 262.

WELCOMME, R.L., WINEMILLER, K.O. and COWX, I.G., 2006. Fish environmental guilds as a tool for assessment of ecological condition of rivers. River Research and Applications, vol. 22, no. 3, pp. 377-396. http://dx.doi.org/10.1002/rra.914.

WILLIS, J.C., 1902. Studies in the morphology and ecology of the Podostemaceae of Ceylon and India. Annals of the Royal Botanic Gardens, Peradeniya, vol. 1, pp. 268-465.

WORLD COMMISSION ON DAMS - WCD, 2000 [viewed 10 October 2015]. Dams and development: a new framework for decision-making [online]. London: Earthscan. Available from: www.dams.org//docs/overview/cmb_sumario.pdf 